\title{
Evaluation of allelopathic potential of Iranian wheat (Triticum aestivum L.) cultivars against weeds
}

\author{
Mohammad Reza Labbafi ${ }^{{ }^{*}}$, Assadollah Hejazi ${ }^{1}$, Fariba Maighany ${ }^{2}$, Hamideh Khalaj $^{1}$, \\ Ali Mehrafarin ${ }^{2}$ \\ ${ }^{1}$ Department of Agronomy and Plant Breeding, Abooreihan Campus, University of Tehran, \\ Pakdasht, Iran, Phone (Office): +98 292 3025200, Fax (Office) +98 2923025200 \\ ${ }^{2}$ Weed Research Department, Iranian Plant Protection Research Institute, Tehran, Iran.
}

\begin{abstract}
The 'equal-compartment-agar-method' was employed to evaluate four allelopathic activity wheat cultivars on whole plant, root and shoot length and plant dry weight of four weed species. Wheat cultivars were included Niknejad and Shiraz (more competitive cultivars); Tabasi and Roshan (less competitive cultivars). In this study used four weed species (Secale cereale L., Avena ludoviciana L.: monocotyledon, Convolvulus arvensis L. and Vicia villosa L.: dicotyledon). Results showed that the allelopathic activity of wheat was associated with number of wheat seedlings and wheat cultivars. Results demonstrated that the whole plant and root length of weed species were significantly reduced in the presence of wheat cultivars. The degree of weed growth inhibition was depended on the number of wheat seedlings. All of the cultivars and densities caused promotion of dicot shoot length. Results indicated that the length of whole plant $(-30.22 \%)$ and root ($57.74 \%)$ of $C$. arvensis and shoot length $(-13.24 \%)$ of $S$. cereale had the highest sensitivity. None of factors had significant effect on plant dry weight of weed species.
\end{abstract}

Keywords: Equal-compartment-agar-method; Wheat Allelopathy; Weed management; sowing density

\section{INTRODUCTION}

Wheat is the main crop in most provinces of Iran. The grain yield reduction due to weed infestation, in no control situation, has been estimated 30\%. Although in different areas, depending on climatic conditions, dominant weed species vary, but some of them are common in most areas. The most prevalent weeds in wheat field are Secale cereale, Galium tricornutum, Convolvulus arvensis, Avena ludoviciana, Phalaris minor, Vicia villosa, and Sinapis arvensis. There are several methods to control of these plants. One of them is putting allelopathic and cover crops in weed management programs (Inderjit et al., 2001; Rovira, 1969). Wheat (Triticum aestivum) has been examined for differential allelopathic potential among accessions. In an experiment examining 286 wheat accessions for their allelopathic potential on the growth of Bromus japonicum and Chenopodium album, Sruell (1984), reported that five accessions produced root exudates that were inhibitorier of the root growth of the receiver plant than a commercial cultivar, T64. More recently, 38 wheat cultivars and durum wheat ( $T$. durum Desf.) were evaluated for their differential allelopathic potential against Lolium rigidum using an extract bioassay (Wu et al., 1998). Some wheat cultivars significantly inhibited both the germination and radicle growth of $L$. rigidum. The allelopathic potential of wheat cultivars was positively correlated with the contents of total phenolic acids. Wu et al., (2000) examined a worldwide collection of 453 wheat accessions for allelopathic suppression on L. rigidum. It was found that 17-day-old seedlings of wheat accessions differed significantly in their allelopathic inhibition on the radicle growth of this weed species. Some accessions inhibited the radicle length of $L$. rigidum by more than $80 \%$ in comparison to non-wheat control. Zheng et al. (25) have reported that the inhibitory ability may be improved by increasing the density of wheat in production. Xu et al. (24) indicated that Barnyard grass plants grew shorter as rice plant density increased. Cheema et al. (4) showed that wheat straw aqueous extract significantly inhibited the germination and growth of sweet potato (Ipomoe batatas) and yellow nutsedge (Cyperus esculentus).

Wild wheat accessions (Triticum speltoides) have also been examined for allelopathic potential in Australia. Hashem and Adkins (6) found that one of 19 accessions of $T$. speltoides significantly inhibited the root length of Avena fatua L. and two out of eight accessions inhibited the radicle length of Sisymbrium orientale L. The possibility of transfer of allelopathic 
potential from wheat progenitors into modern wheat cultivars has been suggested as a means of suppressing weed growth.

The aim of this study was to determine if Iranian wheat cultivar affect seedling growth of some noxious weeds such as (Secale cereale, Avena ludoviciana: monocotyledon, Convolvulus arvensis and Vicia villosa: dicotyledon) that are troublesome in wheat fields.

\section{MATERIALS AND METHODS}

Tested species: This study was performed at Weed Research Department of Iran, Crop protection Research Institute, in 2006. Seeds of wheat (Triticum aestivum) cultivars (Niknejad, Shiraz, Tabasi and Roshan) and seeds of weeds (Secale cereale, Avena ludoviciana, Convolvulus arvensis and Vicia villosa) were obtained from Weed Research Department of Iran, Crop protection Research Institute. Seeds (wheat and weed) were sterilized by soaking them in $70 \%$ ethanol for $2.5 \mathrm{~min}$, followed by 4 times rinsing in sterilized distilled water. Then seeds were soaked in $2.5 \%$ sodium hypochlorite solution for $15 \mathrm{~min}$, followed by 5 times rinsing in sterilized distilled water. Seed pre-germination: Surface-sterilized each of the wheat seeds cultivars and weed seeds species were soaked in sterilized water for imbibitions of water in light at $25^{\circ} \mathrm{C}$ for $24 \mathrm{~h}$ and then rinsed with sterilized water. The wheat and weed seeds were incubated in light at $25^{\circ} \mathrm{C}$ for another $48 \mathrm{~h}$, and weeds seeds incubated in light at $25^{\circ} \mathrm{C}$ for $48 \mathrm{~h}$.

Description of equal-compartment-agar-method: A glass beaker $(800 \mathrm{~mL}$ containing $50 \mathrm{~mL}$ of $0.3 \%$ water agar (no nutrients) was autoclaved. Pregerminated wheat seeds of each cultivar were uniformly selected and aseptically sown on one-half of the agar surface with the embryo up. The beaker was wrapped with parafilm to prevent contamination and evaporation from the agar surface and placed in a controlled environment growth cabinet with a daily light/dark 25/13 cycle of 13/11 h. After growth of wheat seedlings for 7 days, 16 pre-germinated seeds of weed were aseptically sown on the other half of the agar surface. After sowing of weeds, the beaker were again wrapped with parafilm and placed back in the growth cabinet for continuous growth of 10 days. The growth of weeds alone was included as the nowheat as control.

According to the equal-compartment-agar method (ECAM), pre-germinated seeds of wheat cultivars were sown at different densities of 0 (as control), 8, 16 and 24 seedlings in glass beakers pre-filled with
$50 \mathrm{~mL}$ of $0.3 \%$ water agar. Pre-germinated weed seeds were sown 7 days after the sowing of wheat seeds. The whole plant, root and shoot length and plant dry weight of weed seedlings were measured after 10 days of growth in growth cabinet.

Statistical analysis: The experiment was established in a factorial design, completely randomized with 3 replications. There were two factors: wheat cultivars (Niknejad, Shiraz, Tabasi, and Roshan) and wheat density (0, 8, 16 and 24 seedlings). All experimental data were subjected to analysis of variance using SAS (Version 9.1) and the treatment means were tested by Duncan Multiple Range Test. Percentage inhibition on trait of weeds were calculated as treatment $\times 100 /$ control (23).

\section{RESULTS AND DISCUSSION Monocot weeds}

Secale cereale: Significant differences in whole plant length of $S$. cereale was observed in wheat cultivars, density and interaction of cultivar $\times$ density $(p<0.01)$ of wheat. Density $(p<0.01)$ and cultivar $x$ density $(p<0.05)$ of wheat had significant differences on root length of $S$. cereale.

The result showed that $S$. cereale growth was significantly affected by the interaction of cultivar $x$ density. In other words, the wheat density did not follow the similar pattern in all wheat cultivars, as Niknejad $\times 24$ seedlings was maximum decreasing ($31.13 \%$ ) in S. cereale compared to the control (Table 2). Niknejad $\times 24$ seedlings caused $-44.47 \%$ decreases in $S$. cereale root length compared with control (Table 2). The inhibition of weeds whole plant and root length may reflect the allelopathic potential of individual wheat cultivars. Roshan cultivar showed maximum inhibition (-15.35\%) in shoot length of $S$. cereale (Fig. 3). Results of this study are in agreed with results of Kuk Ahn and Chung (9); Inderjit et al. (8); Putnam and Duke (15); He et al. (7); Dilday et al. (5).

None of cultivars had significant different on $S$. cereale dry weight (Fig. 4). Increase density caused decrease in $S$. cereale dry weight without significant differences (Table 1), this results were disagree with the finding of Olfsdotter and Navarez (13) and Olfsdotter et al. (12). Result of present study agree to these results Cheema et al. (4) reported that wheat straw aqueous germination extract stimulated dry matter production of cotton. The inhibition of $S$. cereal whole plant, root and shoot length by wheat cultivars may reflect the allelopathic potential of individual wheat cultivars. Results showed that more and less competitive wheat cultivars caused significant 
differences in $S$. cereale whole and shoot length (Table 3)

Avena ludoviciana: The results showed that wheat cultivar $(p<0.01)$ has significant effect on whole plant and shoot length of $A$. Iudoviciana. Wheat density had effect on whole plant and root length $(p<0.05)$ of A. Iudoviciana. The interaction of cultivar $x$ density of wheat had significant effect $(p<0.05)$ on whole plant length.

A. ludoviciana length was inhibited significant (-26.98 $\%$ ) by Niknejad $\times 8$ seedlings (Table 2). Results showed that the root and shoot length of $A$. ludoviciana, was decreased $-46.09 \%$ and $-4.14 \%$ by Niknejad respectively, compared to control (Fig 2, 3). The magnitude of allelopathic effects varied among the wheat cultivars studied. Results of this study are in agreement with some authors (e.g. Wu et al. (20, 21, 23); Li et al. (10); Perez (14); Rizvi et al. (16); Olofsdotter and Navarez (13)) who concluded that variation in allelopathic activity existed among cultivars.

In present study None of cultivars had significant different on A. ludoviciana dry weight (Fig. 4) agree to these results Kuk Ahn and Chung (9) reported that Thirty-one Hull extracts from 91 cultivated rice cultivars (including 'Baekambyeo' and 'Cheonmabyeo') showed no inhibition or stimulated dry weight accumulation of Barnyardgrass.

Maximum wheat density showed minimum inhibitory and maximum promotion of root and shoot length $26.92 \%$ and $+16.62 \%$ respectively, compared to the control (Table 1). Zheng et al. (25) have reported that the inhibitory ability may be improved by increasing the density of wheat in production but this report opposite to these results us in shoot length. Increase of density caused enhance dry weight but had not significant among densities (Table 1). Results showed significant differences between more and less competitive wheat cultivars in view point of whole and shoot length of $A$. Iudoviciana (Table 3).

Results of this study declared that whole plant and root length of Monocot weeds were significantly reduced in the presence of wheat cultivars. The degree of inhibition was dependent on the number of wheat seedlings. Inhibition caused by different wheat cultivars can be attributed to presence of major(s) controlling the production of allelochemicals like acetic, propionic, butyric, vanillic, syringic, p-coumaric and p-hydroxybenzoic acids which are known to cause reduction in plant growth and act as herbicide $(19,14,2)$.

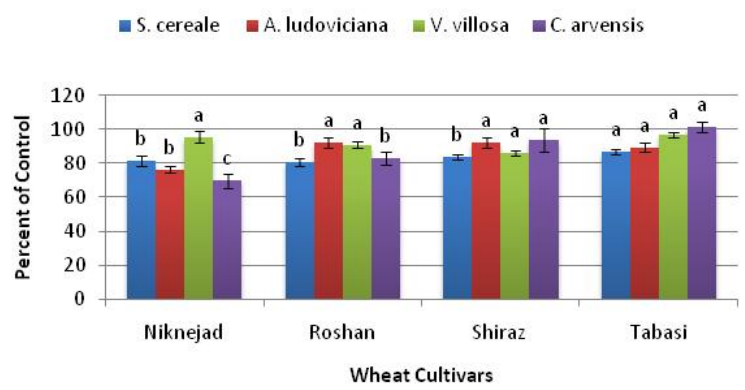

Fig 1. Mean comparison wheat cultivar on whole plant length of weed compared to control (\%)

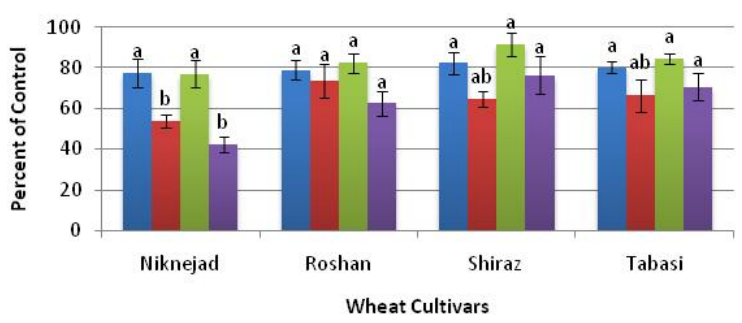

Fig 2. Mean comparison wheat cultivar on Root length of weed compared to control (\%)

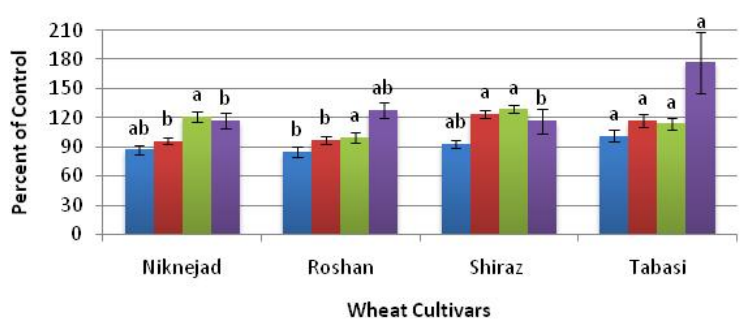

Fig 3. Mean comparison wheat cultivar on Shoot length of weed compared to control $(\%)$

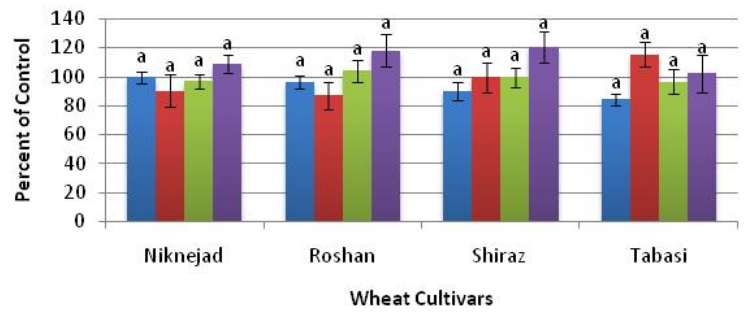

Fig 4. Mean comparison wheat cultivar on plant dry weight of weed compared to control (\%) 
Table 1. Mean comparison wheat density on whole plant, root and shoot height of weed compared to control (\%)

\begin{tabular}{|c|c|c|c|c|}
\hline \multirow{2}{*}{$\begin{array}{l}\text { Wheat density } \\
\text { (seedling in } \\
\text { glass beakers) }\end{array}$} & \multicolumn{4}{|c|}{ Whole plant height } \\
\hline & S. cereale & A. Iudoviciana & V. villosa & C. arvensis \\
\hline $\begin{array}{c}8 \\
16 \\
24\end{array}$ & $\begin{array}{l}86.98 \pm 1.19 a \\
82.48 \pm 1.62 b \\
79.63 \pm 2.39 c\end{array}$ & $\begin{array}{c}88.37 \pm 3.47 \mathrm{ab} \\
83.34 \pm 2.17 \mathrm{~b} \\
90.05 \pm 3.07 \mathrm{a} \\
\end{array}$ & $\begin{array}{l}94.65 \pm 1.19 \mathrm{a} \\
92.46 \pm 1.62 \mathrm{a} \\
91.59 \pm 2.39 \mathrm{a}\end{array}$ & $\begin{array}{l}92.15 \pm 5.32 a \\
94.39 \pm 3.58 a \\
76.55 \pm 5.18 b \\
\end{array}$ \\
\hline \multirow{2}{*}{24} & \multicolumn{4}{|c|}{ Root height } \\
\hline & S. cereale & A. Iudoviciana & V. villosa & C. arvensis \\
\hline $\begin{array}{l}08 \\
16 \\
24\end{array}$ & $\begin{array}{c}87.23 \pm 2.64 \mathrm{a} \\
80.34 \pm 4.15 \mathrm{ab} \\
70.62 \pm 4.98 \mathrm{~b}\end{array}$ & $\begin{array}{c}66.24 \pm 3.32 a b \\
55.18 \pm 3.46 b \\
73.08 \pm 3.16 a\end{array}$ & $\begin{array}{c}95.42 \pm 2.64 a \\
85.37 \pm 4.15 a b \\
70.83 \pm 4.98 b\end{array}$ & $\begin{array}{c}75.29 \pm 8.13 a \\
62.42 \pm 4.11 a b \\
52.72 \pm 6.26 b\end{array}$ \\
\hline & \multicolumn{4}{|c|}{$\begin{array}{l}\text { Shoot height } \\
\end{array}$} \\
\hline $\begin{array}{l}08 \\
16 \\
24\end{array}$ & $\begin{array}{c}\text { S. cereale } \\
93.31 \pm 6.01 \mathrm{a} \\
88.87 \pm 3.62 \mathrm{a} \\
92.19 \pm 4.90 \mathrm{a}\end{array}$ & $\begin{array}{c}\text { A. ludoviciana } \\
102.05 \pm 5.75 \mathrm{~b} \\
106.11 \pm 4.34 \mathrm{ab} \\
116.62 \pm 5.81 \mathrm{a}\end{array}$ & $\begin{array}{c}\text { V. villosa } \\
114.33 \pm 6.01 \mathrm{a} \\
112.39 \pm 3.62 \mathrm{a} \\
120.33 \pm 4.90 \mathrm{a}\end{array}$ & $\begin{array}{c}\text { C. arvensis } \\
128.29 \pm 10.90 a b \\
161.81 \pm 20.19 a \\
108.17 \pm 7.81 \mathrm{~b}\end{array}$ \\
\hline 24 & \multicolumn{4}{|c|}{\begin{tabular}{|l} 
Plant dry weight \\
\end{tabular}} \\
\hline $\begin{array}{l}08 \\
16 \\
24 \\
\end{array}$ & $\begin{array}{c}\text { S. cereale } \\
94.34 \pm 4.80 \mathrm{a} \\
91.88 \pm 3.79 \mathrm{a} \\
90.74 \pm 4.56 \mathrm{a}\end{array}$ & $\begin{array}{c}\text { A. ludoviciana } \\
91.7 \pm 9.15 \mathrm{a} \\
97.84 \pm 9.50 \mathrm{a} \\
105.68 \pm 9.82 \mathrm{a}\end{array}$ & $\begin{array}{c}\text { V. villosa } \\
100.55 \pm 5.38 \mathrm{a} \\
94.24 \pm 7.55 \mathrm{a} \\
102.95 \pm 4.64 \mathrm{a}\end{array}$ & $\begin{array}{c}\text { C. arvensis } \\
111.35 \pm 8.07 \mathrm{a} \\
123.99 \pm 10.50 \mathrm{a} \\
102.4 \pm 010.79 \mathrm{a}\end{array}$ \\
\hline
\end{tabular}

Means with the same letter in each column are not significantly different at probability level of $5 \%$ using DMRT.

Table 2. The interaction between wheat cultivar $\times$ density on whole plant and root height of weed compared to control (\%)

\begin{tabular}{|c|c|c|c|c|c|}
\hline \multirow{2}{*}{$\begin{array}{l}\text { Wheat } \\
\text { cultivar }\end{array}$} & \multirow{2}{*}{$\begin{array}{l}\text { Wheat density } \\
\text { (seedling in } \\
\text { glass beakers) }\end{array}$} & \multicolumn{3}{|c|}{ Whole plant height } & \multirow{2}{*}{$\begin{array}{l}\text { Root height } \\
\text { S. cereale }\end{array}$} \\
\hline & & A. Iudoviciana & C. arvensis & S. cereale & \\
\hline Niknejad & $\begin{array}{c}8 \\
16 \\
24\end{array}$ & $\begin{array}{c}73.02 \pm 1.75 \mathrm{f} \\
75.94 \pm 3.59 \mathrm{f} \\
80.02 \pm 3.11 \mathrm{ef}\end{array}$ & $\begin{array}{c}69.25 \pm 5.04 \mathrm{~cd} \\
82.10 \pm 1.34 \mathrm{bc} \\
62.09 \pm 7.02 \mathrm{~d}\end{array}$ & $\begin{array}{c}89.03 \pm 1.43 \mathrm{ab} \\
86.58 \pm 2.09 \mathrm{abc} \\
68.87 \pm 1.34 \mathrm{e}\end{array}$ & $\begin{array}{c}90.32 \pm 9.38 \mathrm{a} \\
86.22 \pm 6.36 \mathrm{ab} \\
55.53 \pm 8.77 \mathrm{c}\end{array}$ \\
\hline Roshan & $\begin{array}{c}8 \\
16 \\
24\end{array}$ & $\begin{array}{c}89.66 \pm 3.07 \mathrm{cde} \\
86.35 \pm 2.52 \mathrm{cde} \\
104.07 \pm 1.50 \mathrm{a}\end{array}$ & $\begin{array}{l}84.24 \pm 4.87 \mathrm{bc} \\
92.98 \pm 6.00 \mathrm{ab} \\
72.21 \pm 1.74 \mathrm{~cd}\end{array}$ & $\begin{array}{c}81.74 \pm 1.42 \mathrm{c} \\
74.39 \pm 0.85 \mathrm{~d} \\
85.86 \pm 3.03 \mathrm{abc}\end{array}$ & $\begin{array}{l}85.20 \pm 6.53 a b \\
65.61 \pm 8.48 b c \\
85.91 \pm 6.37 a b\end{array}$ \\
\hline Shiraz & $\begin{array}{c}8 \\
16 \\
24\end{array}$ & $\begin{array}{l}101.94 \pm 4.60 \mathrm{ab} \\
88.82 \pm 2.37 \mathrm{cde} \\
87.59 \pm 1.98 \mathrm{cde}\end{array}$ & $\begin{array}{l}106.18 \pm 5.97 \mathrm{a} \\
105.89 \pm 8.82 \mathrm{a} \\
69.09 \pm 2.34 \mathrm{~cd}\end{array}$ & $\begin{array}{c}86.70 \pm 1.70 \mathrm{abc} \\
82.25 \pm 1.14 \mathrm{c} \\
80.99 \pm 5.05 \mathrm{c}\end{array}$ & $\begin{array}{c}87.73 \pm 3.21 \mathrm{ab} \\
88.03 \pm 8.84 \mathrm{ab} \\
65.88 \pm 15.01 \mathrm{bc}\end{array}$ \\
\hline Tabasi & $\begin{array}{c}8 \\
16 \\
24\end{array}$ & $\begin{array}{c}93.38 \pm 3.04 \text { bc } \\
82.27 \pm 5.63 \text { def } \\
92.37 \pm 2.99 \text { bcd }\end{array}$ & $\begin{array}{l}108.91 \pm 2.46 \mathrm{a} \\
92.47 \pm 1.20 \mathrm{ab} \\
102.83 \pm 6.69 \mathrm{a}\end{array}$ & $\begin{array}{c}90.43 \pm 1.57 \mathrm{a} \\
86.71 \pm 1.17 \mathrm{abc} \\
83.25 \pm 1.05 \mathrm{bc}\end{array}$ & $\begin{array}{c}85.65 \pm 1.97 a b \\
81.49 \pm 5.64 a b \\
73.59 \pm 4.49 a b c\end{array}$ \\
\hline
\end{tabular}


Agric Biol J N Am., 2010, 1(3): 355-361

Table 3. Orthogonal comparisons on different combinations of wheat cultivars for whole plant, root and shoot length of weed

\begin{tabular}{|c|c|c|c|c|}
\hline \multirow{2}{*}{$\begin{array}{l}\text { More and less competitive } \\
\text { wheat cultivars }\end{array}$} & \multicolumn{4}{|c|}{ Whole plant length } \\
\hline & S. cereale & A. Iudoviciana & V. villosa & C. arvensis \\
\hline More vs Less & $0.436 \times x$ & $0.929 \times x$ & $0.060 \mathrm{~ns}$ & $10.180 \times x$ \\
\hline Niknejad vs Shiraz (More) & $0.006 \mathrm{~ns}$ & $3.500 \times x$ & $0.311 \mathrm{~ns}$ & $1.971 \times \times$ \\
\hline \multirow[t]{3}{*}{ Roshan vs Tabasi (Less) } & $0.149 \times$ & $0.127 \mathrm{~ns}$ & $0.901 \mathrm{~ns}$ & $0.843 \mathrm{~ns}$ \\
\hline & \multicolumn{4}{|c|}{ Root length } \\
\hline & S. cereale & A. Iudoviciana & V. villosa & C. arvensis \\
\hline More vs Less & $0.204 \mathrm{~ns}$ & $0.036 \mathrm{~ns}$ & $1.803 \mathrm{~ns}$ & $14.345 \times x$ \\
\hline Niknejad vs Shiraz (More) & $0.072 \mathrm{~ns}$ & $7.008 \times$ & $0.419 \mathrm{~ns}$ & $6.992 \times$ \\
\hline \multirow[t]{3}{*}{ Roshan vs Tabasi (Less) } & $0.001 \mathrm{~ns}$ & $0.007 \mathrm{~ns}$ & $0.410 \mathrm{~ns}$ & $0.348 \mathrm{~ns}$ \\
\hline & \multicolumn{4}{|c|}{ Shoot length } \\
\hline & S. cereale & A. ludoviciana & V. villosa & C. arvensis \\
\hline More vs Less & $3.442 \times$ & $10.593 \times x$ & $1.943 \mathrm{~ns}$ & $3.831 \mathrm{~ns}$ \\
\hline Niknejad vs Shiraz (More) & $0.056 \mathrm{~ns}$ & $0.040 \mathrm{~ns}$ & $4.405 \mathrm{~ns}$ & $0.678 \mathrm{~ns}$ \\
\hline \multirow[t]{3}{*}{ Roshan vs Tabasi (Less) } & $0.525 \mathrm{~ns}$ & $0.479 \mathrm{~ns}$ & $1.660 \mathrm{~ns}$ & $18.702 \times$ \\
\hline & \multicolumn{4}{|c|}{ Plant dry weight } \\
\hline & S. cereale & A. Iudoviciana & V. villosa & C. arvensis \\
\hline More vs Less & $952.71 \mathrm{~ns}$ & $4472.55 \mathrm{~ns}$ & $50.37 \mathrm{~ns}$ & $2456.32 \mathrm{~ns}$ \\
\hline Niknejad vs Shiraz (More) & $52.29 \mathrm{~ns}$ & $986.62 \mathrm{~ns}$ & $238.64 \mathrm{~ns}$ & $1248.17 \mathrm{~ns}$ \\
\hline Roshan vs Tabasi (Less) & $156.51 \mathrm{~ns}$ & $41.76 \mathrm{~ns}$ & $41.30 \mathrm{~ns}$ & $4148.09 \mathrm{~ns}$ \\
\hline
\end{tabular}




\section{Dicot weeds}

Vicia villosa: None of factors had significant effect on $V$. villosa (Fig 1, 2, 3, 4). Density of 24 wheat seedlings showed maximum inhibition $(-29.17 \%)$ in root length of $V$. villosa (Table 1). Inderjit et al. (8) claimed that the root length of Lolium perenne after sowing was suppressed by wheat, the extent of which was dependent on the density of wheat seeds. None of traits $V$. villosa had any significant different between more and less competitive wheat cultivars (Table 3).

Convolvulus arvensis: Analysis of variance showed that in whole plant length of $C$. arvensis were significant different $(p<0.01)$ among cultivars. Density $(p<0.01)$ and interaction of cultivar $\times$ density $(p<0.05)$ of wheat showed significant effect on root length, but in shoot revealed significant effect between density $(p<0.05)$.

Whole plant growth of $C$. arvensis affected significantly by the interaction of cultivar $\times$ density of wheat. Niknejad $\times 24$ seedlings had maximum inhibition in (-39/91\%) C. arvensis (Table 2). Results showed that Niknejad had the highest inhibition root length $(-57.74 \%)$ of this weed (Fig 2). Root length was the most reliable parameter because it had high sensitivity to allelochemicals and easy to measure (3). Therefore, root length may be a key parameter to verify allelopathic strength of different wheat varieties. All cultivars caused to promote shoot length (Fig 3). None of cultivars had significant different on C. arvensis dry weight (Fig. 4). Meissner et al. (11) reported bermudagrass residue reduced dry weight of several annual vegetable and agronomic crops. These results are disagreeing with finding us.

The highest density of wheat shown inhibitory in root length $(-47.28 \%)$ and minimum promotion in shoot length $(+8.17 \%)$ of $C$. arvensis, compared to the control (Fig 2, 3). Xu et al. (24) indicated that Barnyard grass plants grew shorter as rice plant density increased. All of cultivars and densities caused promotion of dicot shoot length, this is probably due to competition for light on lesser leaf area. Results of this study are in contrast with those of Al Hamdi et al. (1), Kuk Ahn and Chung (9). No one density had significant different on $C$. arvensis dry weight (Table 1). Inhibitory effect of more and less competitive wheat cultivars were found significant on whole plant and root length of $C$. arvensis (Table 3 )

\section{REFERENCE}

Al Hamdi, B., Inderjit, Olofsdotter, $\mathrm{M}$ and Streibig, J. C. (2001). Laboratory Bioassay for Phytotoxicity: An Example from Wheat Straw. Agro. J. 93:43-48

Alsaadawi, I.S., Zwain, K.H.Y and Shahata, H.A. (1998). Allelopathic inhibition of growth of rice by wheat residues. Allelopathy J. 5:163-169

Belz, R.G and Hurle, K. (2004). A novel laboratory screening bioassay for crop seedling Allelopathy. J. Chem. Ecol. 30:175-198

Cheema, Z.A., Ahmed, S., Majeed, S and Ahmed, N. (1988). Allelopathic effects of wheat (Triticum aestivum L.) straw on germination and seedling growth of two weed species and cotton. J. Weed Sci. Res. 1:118-122

Dilday, R.H., Frans, R.E., Semidey, N., Smith, R.J. and Oliver, L. R. (1992). Weed control with crop allelopathy. Arkansas Farm Res. 41:14-15

Hashem, A. and Adkins S.W. (1998). Allelopathy effects of Triticum speltoides on two important weeds of wheat. Plant Protection Quarterly. 13:33-35

He, H. Q., Shen, L. H., Guo, Y. C., Wang, J. Y. and Lin, W. X. (2004). Genetic diversity in allelopathic rice accessions (Oryza sativa L.). Proceedings of the ${ }^{4}$ th International Crop Science Congress

Inderjit, Olofsdotter, M. and Streibig, J.C. (2001). Wheat (Triticum aestivum) interference with seedling growth of perennial ryegrass (Lolium perenne) of density and age. Weed Tecnol. 15:807-812

Kuk Ahen, J and Chung, I.M. (2000). Allelopathic potential of rice hulls on germination and seedling growth of barnyard grass. Agro. J. 92:1162-1167

Li, X. J., Li, B. H. and Lu, D. Z. (2000). A preliminary study on allelopathic effect of wheat plant extracts on Digitaria ciliaris (L.) Scop. Weed Sci. 3: 4-6 (in Chinese)

Meissner, R., Nel, P.C. and Beyers, E.A. (1989). Allelopathic effect of Cynodon dactylon-infested soil on early growth of certain crop species. Applied Plant Sci. 3:125-126

Olfsdotter, M., Navarez, D., Rebulanan, M. and Streibig, J.C. (1999). Weed suppressing rice cultivars does allelopathy play a role? Weed Res. 39:4441-4454

Olfsdotter, M. and Navarez, D. (1996). Allelopathic rice for Echinochloa crue-galli control. In 'Proceeding of the 2nd International Weed Control Congress'. Copenhagen, Denmark. 1175-1181

Perez, F. J. (1990). Allelopathic effects of hydroxamic acids from cereals on Avena sativa and $A$. fatua. Phytochemistry 29:773-776 
Putnam, A.R and Duke, W.B. (1974). Biological Suppression of Weeds: Evidence for Allelopathy in Accessions of Cucumber. Science 185:370-372

Rizvi, S.J.H., Rizvi, V., Tahir, M., Rahimian, M.H., Shimi, P and Atri, A. (2000). Genetic variation in allelopathic activity of wheat (Triticum aestivum $L$ ) genotypes. Wheat Information Service 91:25-29

Rovira, A.D. (1969). Plant root exudates. Bot. Rev. 35:3537

Spruell, J.A. (1984). Allelopathic potential of wheat accession. Dissertation Abstract Inernational, B. Sciences and Engineering 45: 1102B

Tang, C.S. and Waiss, A.C. (1978). Short chain fatty acids as growth inhibitors in decomposing wheat straw. J. Chem. Ecol. 4:225-232

Wu, H., Pratley, J., Lemerle, D., Haig, T. and Verbeek, B. (1998a). Wheat allelopathic potential against an herbicide-resistant biotype of annual ryegrass. Proceedings of the Australian Agronomy Conference 567-571. Wagga Australia

Wu, H., Pratley, J., Lemerle, D., Haig, T. and Verbeek, B. (1998b). Differential allelopathic potential among wheat accessions to annual ryegrass. Proceedings of the Australian Agronomy Conference 567-571. Wagga Australia

Wu, H., Pratley, J., Lemerle, D. and Haig, T. (2000a). Evaluation of seedling allelopathy in 453 wheat (Triticum aestivum) accessions against annual ryegrass (Lolium rigidum) by the equal-compartmentagar method.Agust. J. Agric. Res. 51:937-44

Wu, H., Pratley, J., Lemerle, D. and Haig, T. (2000b). Laboratory screening for allelopathic potential of wheat (Triticum aestivum) accessions against annual ryegrass (Lolium rigidum). Agust. J. Agric. Res. 51:259-66

Xu, Z., He, Y., Wang, Y. and Yu, G. (2004). Interference of allelopathic rice cultivars on Barnyardgrass under different water irrigation and rice plant density. J. Ying Yong Sheng Tai Xue Bao. 15:1580-1584

Zheng, Y. Q., Zhao, Y., Dong, F. S., Yao, J. R. and Karl, H. (2005). Allelopathic effects of extracts from wheat and its secondary metabolite 2,4-dihydroxy- 7- methoxy -1 , 4-benzoxazin-3-one on weeds. Proceedings of the $4^{\text {th }}$ World Congress on Allelopathy, Wagga, Australia 